\title{
ESTABLISHING AND MAINTAINING KNOWLEDGE MANAGEMENT IN THE ENTERPRISES OF THE DEFENSE INDUSTRY
}

\begin{abstract}
Marko R. Bojić*
Slobodan Lj. Stanojevic**

Milorad Č. Zekić ${ }^{* * *}$

Достављен: 14. 07. 2020

Језик рада: Енглески

Прихваћен: 10. 09. 2020

Тип рада: Прегледни рад

DOI бpoj: 10.5937/vojdelo2002098B

Establishing knowledge management means setting up, maintaining and constantly updating a state by generating new models and rules of its use, i.e. means process. Each process takes place in accordance with a logical structure and certain rules, supported by someone.It has a specific goal, directed content and it requires some assumptions,that is, characteristics of the environment in which it takes place. When it comes to knowledge management, its establishment and maintenance, the enterprises of the defense industry represent the environment and its properties condition the generation of knowledge management. On this assumption, questions can be asked and their answers explain the knowledge management generation.
\end{abstract}

Key words: the enterprises of the defense industry, analysis, knowledge, management

\section{Introduction}

In the current reality, it is noticeable that both the enterprises of the defense

industry and their environment are diversifying into an increasing number of elements or parts, which increases their complexity. All of this provokes the increased attention and ability to grasp complexity above all as a business-environment relationship. This problem of understanding complexity occurs at all levels of integrative management, but they always arise as a matter of self-awareness of the state of the enterprises of the defense industry system. By its dimension, the level of mana-

\footnotetext{
* Public Library "Radoslav Nikčević", Kneginje Milice 2-4 Street, 35000 Jagodina.

** Faculty of Applied Management, Economics and Finance, Jevrejska 24/1 Street, 11000 Belgrade, sloba.stan1976@gmail.com

*** School of Economics and Management Studies, Karađorđeva 52 Street, 34000 Kragujevac.
} 
gement is the primary normative level because it predetermines the components and stages of the constitution of the enterprises of the defense industry and its management subsystem at the strategic and operational levels; therefore, the meaning of self-awareness is viewed precisely at the normative level.

At the normative level, the management problem is the constitution of the enter-prises of the defense industry philosophy and management philosophy. Aligning philosophies means creating the preconditions for shaping the vision and culture of the enterprises of the defense industry and military organizations, which determines all decisions and ways of solving management problems at the strategic and operational levels ${ }^{1}$ in all the abovementioned aspects of selfrealization and selfawareness, which is clearly illustrated by the following questions: what is the essence of knowledge management generation and which approach is adequate, what is the goal or what is there to be learned and loaded into knowledge management, who is learning or who is generating knowledge management, what is the basis of learning and knowledge management generation and what are the essential assumptions of learning or knowledge management generation?

The answers to these questions explicate the necessary assumptions for a deliberate, goal-oriented knowledge management design and determine the nature of the process of establishing, maintainingand updating knowledge management.

\section{Knowledge management generation approaches}

While observing the development of the system, a particular form has been observed in which the efficiency and effectiveness of the system increase without the introduction of new material and energy components. The development is achieved by changing the internal composition of the system, i.e. the elements that make connections, the forms of relationships and relationships change; a new composition is established. All these changes have been made on the basis of the knowledge that the existing composition limits the growth of effectiveness and/or efficiency, on the one hand, and the basis of new knowledge that a new composition is possible, which removes such limitations, on the other. In the context of the knowledge management content it can be said that the system, i.e. the enterprises of the defense industry have disposed of or remembered and used knowledge of one type of structural and functional models and that, using the rules of disposal of information, it has noticed the possibility of their improvement. ${ }^{2}$ The possibilities for better composition have been identified by gathering information or knowledge that has existed in other companies, that is, in the environment, or have been generated in the enterprises of the defense industry. All of this has happened during internal and reversible action with the environment.

\footnotetext{
${ }^{1}$ Branimir Vulević i Anja Božović, „Menadžment kvaliteta i zaštite životne sredine u vojnim organizacijama“", Vojno delo, Vol. 69, No. 7, 2017, str. 261-275.

2 Tatiana Andreeva and Aino Kianto, „Does knowledge management really matter? Linking knowledge management practices, competitiveness and economic performance", Journal of Knowledge Management, Vol. 16, No. 4, 2012, pp. 617-636.
} 
This form of development is referred to as learning, so it can be said that knowledge management as memorable a priori information in models and rules, as well as changing and remembering new models and rules is nothing but learning; ${ }^{3}$ learning every enterprise, as well as the enterprises of the defense industry is the essence of designing and maintaining knowledge management.

The claims about complex image and the integration of different insights into a comprehensive picture have implied the rules of knowledge management creation and development; impact recognition and image formation are due to structural and process complexity. In simplistic terms, recognizing influence and forming an image are the result of a way of thinking, and the way of thinking, especially the way of thinking of business economics, is not, as we know, the same., ${ }^{4,5}$ The path from engineering to systems science of the enterprises of the defense industry economics is a long one and not yet completed. If the picture of business networking in a pile is supplemented by the connections and relationships of aspects from which one observes the possibility of survival, a very complex network is obtained. A way of showing networking is to change the mindset of a business (see Figure 1).

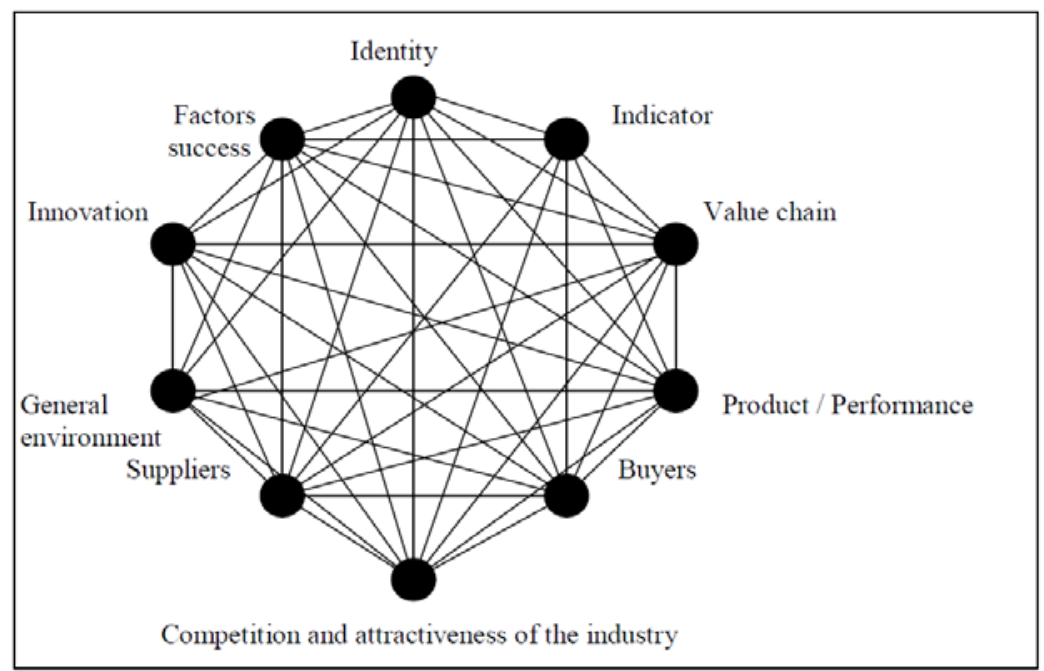

Figure 1 - The enterprises of the defense industry as a networked system (Top 5 Reasons Why Knowledge Management is Necessary, BroadVision Inc)

\footnotetext{
${ }^{3}$ Elias M Award and Hassan M. Ghaziri, Knowledge Management, Pearson Education International. Prentice Hall, New Jersey, 2004

${ }^{4}$ Ganesh D. Bhatt, „Knowledge management in organizations: examining the interaction between technologies, techniques, and people“, Journal of Knowledge Management, Vol. 5, No. 1, 2001, pp. 68-75

${ }^{5}$ Miroslav Čavlin, Rade Žugić i Vladimir Prebiračević, „Karakter planiranja kao funkcije menadžmenta", Oditor - časopis za Menadžment, finansije i pravo, Vol. 3, No. 1, 2017, str. 102113. ${ }^{6}$ Milenko Dželetović, Branislav Mašić, Davor Nikolić i Sandra Nešić, „Menadžment znanja i konkurentnost organizacije“, Poslovna ekonomija, Vol. 10, No. 2, 2016, str. 118-139.
} 
Such a view is followed by an observation about the way of thinking. In business, as in politics, linear thinking has come to an end. Future success will not be achievable with the measures and instruments that were once used, and the differences between linear and networked thinking have been noted.

The explication of differences confirms the importance and necessity of a networked way of thinking and a systematic approach. This kind of thinking and approach are objectively causal. Influenced by the turbulence of the economic and technical environment, deregulation, internationalization and globalization of markets, increasing networking of economic, social, political and environmental factors and the like, influenced by Bleicher ${ }^{6}$, and especially influenced by the opposite tendencies of integration of the world economics and fragmentation of the world political system, as Drucker claims ${ }^{7}$, the complexity of social systems is rapidly increasing. Each period has its own rhythm of events and its own way of thinking. The increase in complexity is a consequence of the transition from preindustrial via industrial to post-industrial society.

In the conditions of high complexity and rapid change of demands or turbulence, the environment is gaining its importance with goal-oriented response through conceptually unambiguous, but structurally and procedurally different solutions; in a turbulent or extremely dynamic environment, routinely algorithmic management problem - solving is increasingly being replaced or supplemented with innovative non-standard solutions - the importance of intuition, invention and innovation is increasing. This is so because our accumulated experience with simple systems is a poor guide to mastering complex, networked systems. Maintaining integrity is a necessity that requires an adequate way of thinking and acting. ${ }^{8}$ Every single structural and/or process change needs to be understood and carried out by simultaneously networking all dimensions. The evolutionary form of development involves the constant change of states, transition from one state to other within a changed, but always uniquely networked whole; the ability to maintain integrity in change is the ability to survive. The gradualness and continuity of change are part of the general process of evolution of everyone capable of developing a system including businesses. ${ }^{9}$ The essence of dialectic law corresponds to the evolutionary nature of change, so even development as a movement through life cycle stages can be explained by invention, innovation, entrepreneurship and quality improvement as forms of development dialectics. If change is a key feature of

\footnotetext{
${ }^{7}$ Venkat Ram R. Thumiki, Ana Jovancai-Stakić, Said Sulaiman R. Al Barwani, „Efekti kriznih HR strategija primenjenih za vreme trenutne ekonomske krize u Omanu - stanovište jednog HR menadžera", The European Journal of Applied Economics, Vol. 16, No. 1, 2019, str. 77-98.

${ }^{8}$ Suzana Mićović i Jovana Miletić, „Poslovni subjekt kao osnova održivosti razvoja“, Održivi razvoj, Vol. 1, No. 1, 2019, str. 41-49.

${ }^{9}$ Martin Ihrig and lan Mac Millan, „Managing your mission-critical knowledge“, Harvard business review, Vol. 93, No. (1-2), 2015, pp. 81-87.
} 
survivability, ${ }^{10}$ and if, in the face of growing complexity, regardless of the size of the enterprises of the defense industry, managing change and making the assumptions of evolutionary development implies inventiveness and innovation, entrepreneurship and quality care as the basis of the enterprises of the defense industry significance, then it can be concluded that dialectical systemic thinking and designing a business offers acceptable conception and rules for generating knowledge management suitable for understanding and managing change and evolutionary development.

\section{The goal of learning and knowledge management generation}

When it comes to the question of what knowledge management is used for, knowledge management is said to be used because it enables the identification, understanding and resolution of management problems. In summary, management issues are listed as problems of liquidity, results and competitive advantage. On this basis, it is also possible to seek the answer to the question of the learning objective. It comes down to the hallmarks of knowledge that one has to acquire to effectively deal with management problems.

Many dominant viewpoints, which competitive advantage is considered from, have the roots in traditional economic theory, which emphasizes market power and industrial structure as determinants. In such a theoretical context, the enterprises of the defense industry strategies are shaped in such a way that, in a changing environment, combining the strengths of firms with environmental opportunities protects competitive advantage. According to such views, the strategy of the enterprises of the defense industry is predetermined by the environmental conditions and the importance of the industry. However, there are recent studies that emphasize the resources or skills-based (resource-based or skill-based) dimensions of the strategy, on the one hand, and on the other, emphasize an organization that develops the enterprises of the defense industry properties such as a set of unique skills and abilities that influence the evolution and design of strategic growth alternatives. ${ }^{11}$ The resource-based approach suggests that internal communities, such as particularly solitary models of learning and accumulating (tangible and intangible) assets, have a significant impact on a firm's ability to develop new products and processes for different markets, and more than that, the firm's competitive capabilities are derived from unique knowledge. This setting confirms that learning and acquiring certain knowledge is a condition for successful resolution of one of the basic management problems. Insights into the model of such learning, its elements, and how it operates are good assumptions for explaining the goal of learning. This specifies what kind of knowledge to acquire.

10 Jay Liebowitz, Beyond Knowledge Management: What Every Leader Should Know, Auerbach Publications, 2011.

${ }^{11}$ Milan Mihajlović, „Odnos menadžmenta preduzeća i korporativnog upravljanja“, Oditor časopis za Menadžment, finansije i pravo, Vol. 2, No.1, 2016, str. 4-10. 
From the point of view of the question of what the goal is, or what is there to be learned and deposited in knowledge management, the answer can be found in the content of the elements that precede knowledge management. In the first place there is universal and tacit knowledge (Universal and Tacit Knowledge). General knowledge is generic and every firm can establish it without great difficulty. This knowledge is embedded in products in forms such as drafts, technical specifications, standardized designs that are taken from the environment, so that other companies can easily understand them as information and imitate them. Download methods can be very different. $^{12}$ Using a product can reverse the way it has been made; by collaborating on joint ventures, such knowledge can be acquired from partners. This knowledge is transparent, therefore it is also called explicit knowledge. Invisible or hidden knowledge has different meaning. First of all, it is created within the enterprises of the defense industry and is accumulated as knowledge of successful solutions and ways of solving management problems. For example, the skills that have proven necessary to successfully introduce a new production process are often so specific to the organization or team members that individuals outside the enterprises of the defense industry cannot easily copy them. This example shows that invisible knowledge can be acquired by using a general result. Nevertheless, the invisible knowledge thus acquired is a specificity of the enterprises of the defense industry, it exists in the form of metaphors and it cannot be often documented or decoded. Using metaphors creates a specific language of the defense industry enterprises that effectively transmits and stores information, but is also a barrier to external use. This form of knowledge is richer than the general, explicit type and it is a significant element of competitive advantage. Due to its non-transparency, it is also called implicit knowledge.

Finally, in response to the question of what to learn in knowledge management, it can be said that ${ }^{13}$ :

1. you have to acquire universal and specific or invisible knowledge of the defense industryenterprises; usually general or universal knowledge is a prerequisite for creating the invisible one, which, as a form of existence and embedded in the way of thinking and results of business, is not easily accessible to competition, and it is an essential element of dynamic fundamental capabilities.

2. Experimentation generates invisible knowledge that enables continuous slight improvements, but also creates new procedures and approaches to management problems, and

3. Dynamic routine also generates invisible knowledge as it enables the development of new skills and abilities to define and solve management problems in a complex way and to support a complex way of perceiving.

${ }^{12}$ Nevena Mihajlović i Marina Apostolovska, „Inženjering liderstva za uspešno poslovanje organizacije", Serbian Journal of Engineering Management, Vol. 3, No. 1, 2018, str. 30-34.

${ }_{13}$ Miloš Nikolić, Marija Marković-Blagojević i Dušan Jerotijević, „Strategijsko upravljanje ljudskim resursima uz primenu informaciono-komunikacionih tehnologija“", Trendovi u poslovanju, Vol. 7, No. 2, 2019, str. 45-56. 


\section{Knowledge management regenerating entities}

In modern approaches, the enterprises of the defense industry are understood as a system and management as a cyber problem. It is generally accepted to distinguish between the first and second order cybernetics, in which the position of management is understood in the context of "the cybernetics of the observed system", so it is a separate control unit (cybernetics of the first order) or it is understood in the context of "the cybernetics of the observing system" and it is the management of an unmanaged control unit (second order cybernetics). It is observed that in modern conditions, the theory of the defense industry enterprises and management theory are increasingly oriented towards secondorder cybernetics, according to which the enterprises of the defense industry and its management function as open, autonomous and self-organizing systems. Unlike the deterministic one, in the self-organizing concept or the concept of "secondorder cybernetics", the system and each of its subsystems have the properties of a subject and an object of management; the result is an increase in feedback, which affects the stability of the system, on the one hand, and the change in the role of management, on the other. ${ }^{14}$ The deterministic concept or cybernetics of the first order leads the management towards limiting the degree of freedom to manage the work, while the concept of selforganization leads the management to raise the degree of freedom of the managed system. In the latter concept, each enterprise of the defense industry subsystem has some degree of freedom in all aspects of management; governance occurs as a degree of freedom in self-formation, self-management and self-development, which is a prerequisite for the evolutionary type of development. ${ }^{15}$ This change is objectively set by increasing the complexity of the enterprises of the defense industry and its environment. Self-design, selfmanagement and self-development as a way of functioning of the enterprises of the defense industry require the construction and permanent upgrading of knowledge management that extends beyond the boundaries of management. It is not difficult to conclude that, in the conditions of high complexity and adequate form of business organization, the existence and development of harmonious knowledge management is necessary, so it follows that management and all associates, or the enterprises of the defense industry as a whole, have to continuously learn and maintain, expand and change by learning knowledge management.

${ }^{14}$ Gary A. Yukl, Leadership in Organizations, 8th Edition, Pearson Education Inc., Prentice Hall, New Jersey, 2013.

${ }^{15}$ Stefan Milosavljević, Đorđe Pantelejić i Dejan Međedović, „Primena i mogućnost unapređenja ekonomskih činilaca u realizaciji održivog razvoja“, Održivi razvoj, Vol. 1, No. 1, 2019, str. 7-14. 


\section{Knowledge management learning and generation basis}

Knowledge management is placed in the context of management and decisionmaking, that is, solving management problems, and thus their firm connection is inferred. This connection is also confirmed in the field of learning. The development and effects of fundamental dynamic capabilities mean that meta knowledge is transformed into the ability to solve managerial problems of strategic nature. In addition, it is not only about setting goals and tasks, but also about correcting them when they are not achieved or are no longer relevant. Reinforcing the positives or dampening the negative parts of the business and the environment is an ongoing process in which the management function proves to be a networked regulatory circle.

The initiation of the need for a solution comes from the alignment of the goal or task on the one hand and the action of the achieved result on the other. The result is the accomplishment of formulated goals and set tasks, and as such confirms or denies the existing skills and competences or knowledge. The need to learn or to create new knowledge, ways of solving problems and skills is generated from management needs. Learning happensin connection with problem solving, so it can be stated that the basis of learning is the real activity of the enterprises of the defense industry and the solution of the real problems related to that activity. Since, in principle, managerial problems are divided into operational and strategic ones, the related learning differs according to backgrounds and ways.

It is noticeable that the learning assumption is the existence of the cybernetic assumption of the management process as a networked regulatory circuit, or that, as it is commonly said, the learning assumption is the existence of well-defined scope. From the differences in the shape of the established circles or the shape of the defined scope, the forms and possibilities of learning are derived as follows ${ }^{16}$ :

1. Single-Loop-Learning

2. Double-Loop-Learning

3. Deutero Learning

Single-Loop-Learning (S-L-L) occurs when information about the results of transformational processes is returned to the beginning of the process with the intention of controlling it. The process can be illustrated by the scheme (Figure 2).

The process consists first in observing the results and returning them to the beginning of the process as information, where they are compared to the standard, desired results, so that if the difference arises, there is the initiator or learning potential. Without noticeable difference there is no news, no new information and there is nothing new to learn. However, the perceived difference requires changes that, by trial and error, actualize the old or generate new abilities, until the result equals the intended, standardized task. Remembering all the tried and tested combinations of routines, skills, or general approaches and procedures, especially

\footnotetext{
${ }^{16}$ Aleksandra Stanković, Milutin Pećić i Bojana Ostojić, „Važnost ljudskih resursa u poslovnom odlučivanju“, Vojno delo, Vol. 70, No. 7, 2018, str. 431-446.
} 
remembering the combination that achieves the normalized result, is the memory of successful or unsuccessful combinations. It is the assimilation of information about new abilities; knowledge management has been expanded with the knowledge of possible adaptations.

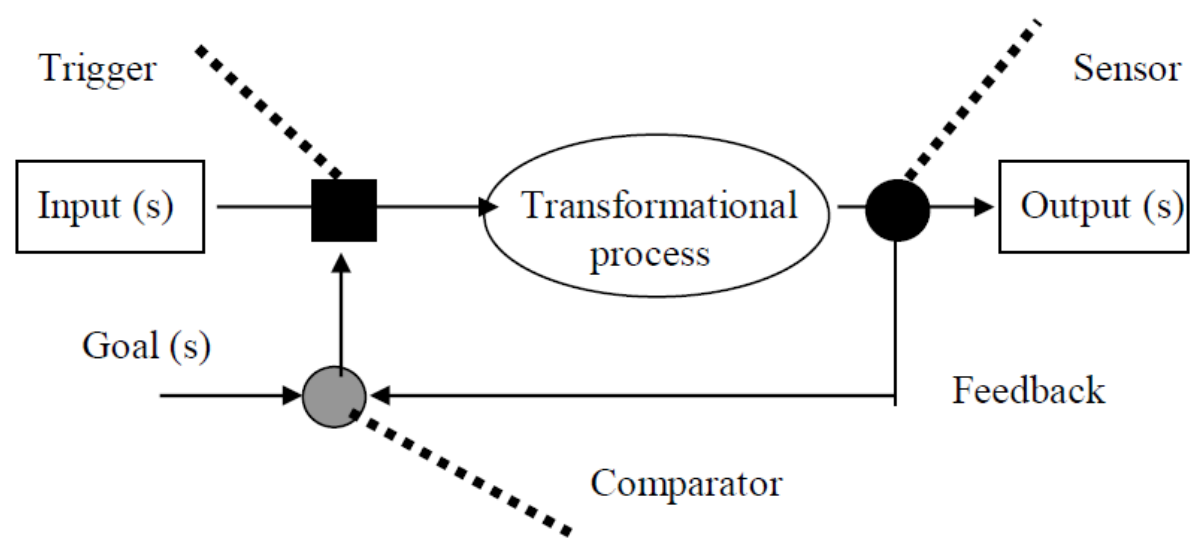

Figure 2 - Single loop learning model

(The American Productivity \& Quality Center (APQC), APQC's 2015 Knowledge Management Conference)

In single-loop learning, attention is focused on the process as well-defined scope. Starting from the elements that define the transformation process, the starting points and their corresponding questions are defined and the answers that contain information to be assimilated are sought. The same source offers the following starting points and questions ${ }^{17}$ :

- Inputs and outputs "What transforms into what?"

- The process of "How is transformation performed?"

- Objectives "Why is transformation underway?"

- Feedback "How well does transformation work?"

He then concludes that the value of such defining a starting point for understanding the scope or model of the process is demonstrated by showing how these questions and the answers contained therein are interrelated in a logical whole.

From the questions and the assumed answers, it can be noticed that these are management problems of operational nature. Single-loop learning is oriented towards learning about individual processes and aspects of transformation processes without noticing and appreciating the whole system. The goal and the underlying assumptions are not called into question; it is knowledge of correction at the level of particular actions or processes. Learning using a single loop is partial.

${ }^{17}$ Solomon Abayomi Olakojo, „Seasonal labour market rigidities: Impact on farm employment and wages in Nigeria“, Ekonomika poljoprivrede, Vol. 63, No. 4, 2016, pp. 1123-1140. 
Double-Loop-Learning (D-L-L) appears because the S-L-L has serious limitations. In every situation where, due to the large difference between the achieved and the standardized result, the process corrections do not ensure the achievement of a goal or do not allow survival of a goal and higher-order task, it is necessary to check/control the goals and establish a new regulatory cycle or an additional loop. If the process is controlled and cognized in the first loop, or the knowledge of "doing the right thing" or seeking to answer the question "how the transformation is done", the second loop controls the thing or seeks to know what a "good thing" is or tends to get the answer to the question "why the transformation is done". In these situations, the question is set goals and basic assumptions. The knowledge required to change goals and basic assumptions is the potential of double-loop learning (Figure 3 ).

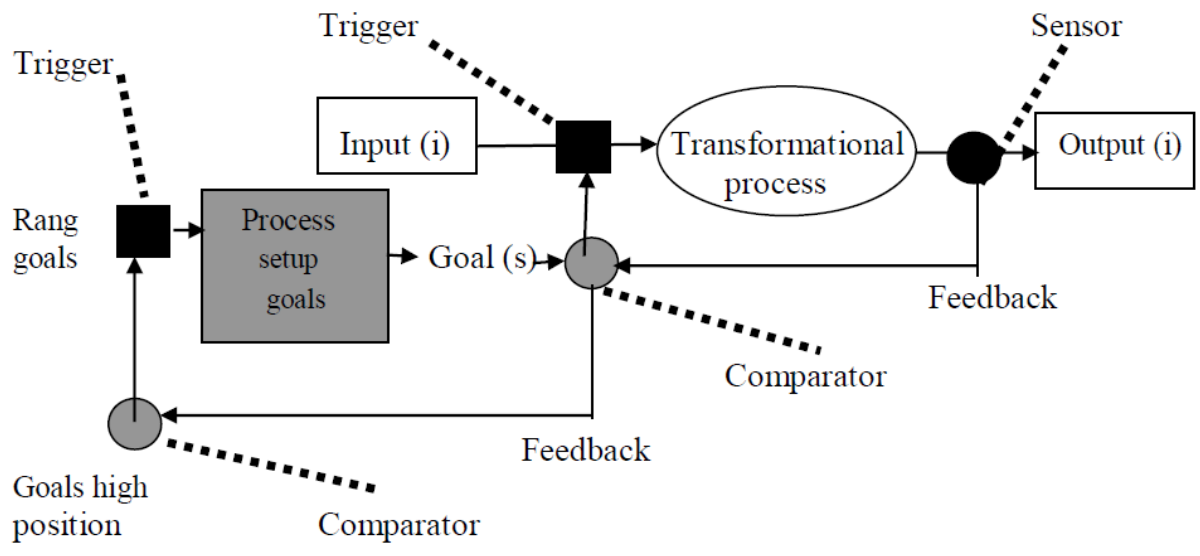

Figure 3 - Double loop learning model

This change involves changing the interaction with the environment or changing assumptions and attitudes toward the environment. All attempts, especially successful attempts to change effects or find a good thing and change the way of effective performance in the environment or change the behavior, are remembered as learning a new approach and new basic abilities. If, in order to achieve different goals and establish different relationships with the environment, it is necessary to change the way of operational execution, it changes. It covers strategic and operational thinking, finding solutions and acting; two loops are connected. Of course, the basic guidelines have been retained, which means that on one side there is the already mentioned initiation of activity, the desired or standardized result, the execution of the process and the actual result, and the other side or the return direction leads to recognition. Knowledge management is assimilated and expanded by information about new goals, approaches, problem-solving procedures and goals and results achieved. 
Deutero Learning appears in response to the limitations of the S-L-L and D-L-L learning models. Not only the way of behavior, but also the way of thinking has to be reviewed and changed. This requires all members of the community organization to openly reflect, review and modify their individual and organizational goals and values. When an organization opts for Deuterolearning, all employees need to learn something about the existing relationships where learning is taking place. They check and analyze previous successes and failures of organizational learning. They need to understand what their activities make learning difficult or easier, devise new learning strategies and note. Revealing and modifying value attitudes and giving up the defensive level is not aimed at checking and changing the memorized and learned as a result of the learning process. It aims to test the possibility of changing the way or process of learning.

It is not difficult to conclude that all three forms of learning differ from one another in well-defined scope, which they view as a loop, and in the content of the knowledge or information thus obtained. However, all three forms of learning have common characteristics, as they generate new information or goal-oriented knowledge and because they take place in a real-world management process with the cyber assumption of the management process as a networked regulatory circle.

\section{Knowledge management generation assumptions}

Organizational learning begins as individual learning in the context of an organization and results as a collective phenomenon of storing knowledge in organizational subsystems about culture (values, norms), structure (programs, manuals) or strategy (strategic goals and behaviors). Although the terms "learning business" or "learning organization" are relatively new reality, "business learning" is not new, but the trauma is even more topical because doing business alone is not enough: ${ }^{18}$

- Solve immediate problems, and

- Learn from the process of solving these problems.

Business is understood as an experiment rather than the search for the "right answers." It is in this context that the question of what the essential assumptions of learning are is asked. These assumptions are relevant both from the point of view of the interdependence of the components within the process, on the one hand, and from the standpoint of the description of the condition, on the other.

Simply put, learning occurs on the basis created by the interdependencies of incorporating individual ideas into the enterprises of the defense industry policy, its operationalization into real business that takes place as a combined activity of numerous individuals. Today, analysis should be interpreted as creating knowledge in an environment of open fuzzy systems or in the context of "the cybernetics of observing system".

\footnotetext{
${ }^{18}$ Mihailo Ćurčić, Radan Kostić i Tanja Arapović, „Planiranje i kontrola kao funkcije menadžmenta preduzeća“, Oditor - časopis za Menadžment, finansije i pravo, Vol. 4, No.1, 2018, str. 94-103.
} 


\section{Conclusion}

One can now answer the questions related to the place of business analysis in the general networking of the enterprises of the defense industry regulatory circle.

Business analysis is a necessary guideline of the general regulatory circle because it generates feedback as a target, wholly closing it under the condition that it is constituted as an entity and a process that includes knowledge of the survival and development of all other business signals subordinated to it, designed to solve problems of relevant information and formulation of criteria for evaluation and selection of the most favorable solution to management problems.

Business analysis justifies its place in the regulatory circle if it is capable of generating new, goal-directed knowledge, so the business analysis process is properly understood only if it is understood as the process of generating new information or new goals and tasks of directed knowledge. A typical example of misunderstanding of the analysis can be found in the business report when it is written: As the above chart and the table shows the realized profit is less than planned and by several percent higher than last year. If it is visible from the chart and if it has been previously recorded in accounting, such record does not carry any new knowledge and even less, for unexplained reasons, it does not contain any purpose-directed knowledge.

Business analysis proves necessary and is generated because, due to the specificity of the enterprises of the defense industry, it mediates theoretical knowledge of the science of business economics in the ability to solve management problems because it generates the necessary new information, enables knowledge and understanding of the stage or reaches the stage of development, and within that stage enables learning and understanding the existence or necessity of a state of stabilization or change, whereby all other information is generated and understood in the context of the stage of developing methodologies to enable formation of a priori information on the structural processual models of the enterprises of the defense industry and the rules of handling information and assumptions used to generate knowledge management and organized learning of the defense industry enterprises.

\section{Literature}

[1] Aleksandra Stanković, Milutin Pećić i Bojana Ostojić, „Važnost ljudskih resursa u poslovnom odlučivanju“, Vojno delo, Vol. 70, No. 7, 2018, str. 431-446.

[2] Branimir Vulević i Anja Božović, „Menadžment kvaliteta i zaštite životne sredine u vojnim organizacijama“, Vojno delo, Vol. 69, No. 7, 2017, str. 261-275.

[3] Dmilenko Dželetović, Branislav Mašić, Davor Nikolić, i Sandra Nešić, „Menadžment znanja i konkurentnost organizacije", Poslovna ekonomija, Vol. 10, No. 2, 2016, str. 118-139.

[4] Elias M Award and Hassan M. Ghaziri, Knowledge Management, Pearson Education International. Prentice Hall, New Jersey, 2004. 
[5] Ganesh D. Bhatt, „Knowledge management in organizations: examining the interaction between technologies, techniques, and people", Journal of Knowledge Management, Vol. 5, No. 1, 2001, pp. 68-75.

[6] Gary A. Yukl, Leadership in Organizations, 8th Edition, Pearson Education Inc., Prentice Hall, New Jersey, 2013.

[7] Jay Liebowitz, Beyond Knowledge Management: What Every Leader Should Know, Auerbach Publications, 2011.

[8] Martin Ihrig and lan Mac Millan, „Managing your mission-critical knowledge“, Harvard business review, Vol. 93, No. (1-2), 2015, pp. 81-87.

[9] Mihailo Ćurčić, Radan Kostić i Tanja Arapović, „Planiranje i kontrola kao funkcije menadžmenta preduzeća“, Oditor - časopis za Menadžment, finansije i pravo, Vol. 4, No.1, 2018, str. 94-103.

[10] Milan Mihajlović, „Odnos menadžmenta preduzeća i korporativnog upravljanja“, Oditor - časopis za Menadžment, finansije i pravo, Vol. 2, No.1, 2016, str. 4-10.

[11] Miloš Nikolić, Marija Marković-Blagojević i Dušan Jerotijević, „Strategijsko upravljanje ljudskim resursima uz primenu informaciono-komunikacionih tehnologija“", Trendovi u poslovanju, Vol. 7, No. 2, 2019, str. 45-56.

[12] Miroslav Čavlin, Rade Žugić i Vladimir Prebiračević, „Karakter planiranja kao funkcije menadžmenta“, Oditor - časopis za Menadžment, finansije i pravo, Vol. 3, No. 1, 2017, str. 102-113.

[13] Nevena Mihajlović i Marina Apostolovska, „Inženjering liderstva za uspešno poslovanje organizacije", Serbian Journal of Engineering Management, Vol. 3, No. 1, 2018, str. 30-34.

[14] Solomon Abayomi Olakojo, „Seasonal labour market rigidities: Impact on farm employment and wages in Nigeria“, Ekonomika poljoprivrede, Vol. 63, No. 4, 2016, pp. 1123-1140.

[15] Stefan Milosavljević, Đorđe Pantelejić i Dejan Međedović, „Primena i mogućnost unapređenja ekonomskih činilaca u realizaciji održivog razvoja“, Održivi razvoj, Vol. 1, No. 1, 2019, str. 7-14.

[16] Suzana Mićović i Jovana Miletić, „Poslovni subjekt kao osnova održivosti razvoja“, Održivi razvoj, Vol. 1, No. 1, 2019, str. 41-49.

[17] Tatiana Andreeva and Aino Kianto, „Does knowledge management really matter? Linking knowledge management practices, competitiveness and economic performance", Journal of Knowledge Management, Vol. 16, No. 4, 2012, pp. 617-636.

[18] Top 5 Reasons Why Knowledge Management is Necessary, BroadVision Inc,. June 10, 2019. www.broadvision.com/en/blog/top-5-reasons-knowledgemanagement

[19] The American Productivity \& Quality Center (APQC), APQC's 2015 Knowledge Management Conference. The Recap, 2015. June 10, 2019 na www.apqc.org/apqcs2015-knowledge-management-conference

[20] Venkat Ram R. Thumiki, Ana Jovancai-Stakić, Said Sulaiman R. Al Barwani, „Efekti kriznih HR strategija primenjenih za vreme trenutne ekonomske krize u Omanu stanovište jednog HR menadžera", The European Journal of Applied Economics, Vol. 16, No. 1, 2019, str. 77-98. 


\section{Успостављање и одржавање управљања знањем у предузећима одбрамбене индустрије}

Управљање знањем је неопходно у циљу државног напретка и зато је од изузетног значаја његово константно ажурирање имплементацијом нових модела и правила коришћења што га чини комплексним процесом. Сваки процес се одвија у складу са логичком структуром и неким правилима, неко га подржава, има одређени циљ, усмерени садржај и захтева неке претпоставке, неке карактеристике средине у којој се одвија. Када је реч о управљању знањем, његовом успостављању и одржавању, тада предузећа одбрамбене индустрије представљају животну средину и његова својства условљавају генерисање управљања знањем. Под овом претпоставком могу се поставити питања чији одговори објашњавају стварање менаџмента знања.

Кључне речи: предузећа одбрамбене индустрије, анализа, знање, управљање 